\title{
MENINGKATKAN PRESTASI BELAJAR SISWA PADA PELAJARAN PLANTAE MENGGUNAKAN MODEL PEMBELAJARAN DISCOVERY LEARNING
}

\author{
Asfarneli*1 ${ }^{1}$, Iwan Ridwan Yusup ${ }^{2}$ \\ MAN 2 Kota Bandung; Jl. Desa Cipadung No.57 Tlp. 022) 7811725 Kel. Cibiru Kota \\ Bandung 40615; \\ Program Studi Pendidikan Bioogi, Program Sarjana S1, Universitas Islam Negeri Sunan \\ Gunung Djati Bandung; Jl. A.H. nasution No. 105 Cibiru- bandung 40614 /Tlp. 022-7802276 \\ Fax. 022-7802276/ www.ftkuinsgd.ac.id \\ asfarneligeulis@yahoo.co.id; iwanyusup@uinsgd.ac.id
}

\begin{abstract}
Abstrak: Tujuan penelitian ini adalah mengetahui peningkatan hasil belajar siswa kelas X MIA 5 pada pelajaran biologi kompetensi dasar Plantae menggunakan model pembelajaran Discovery Learning di MAN 2 Kota Bandung. Metode yang digunakan dalam penelitian ini adalah penelitian tindakan kelas (PTK). Dilakukan sebanyak 2 siklus. Setiap siklus dilakukan 2 kali pertemuan. Teknik pengumpulan datanya menggunakan observasi dan tes. Adapun teknik analisis datanya menempuh deskripsi kegiatan pembelajaran guru dan siswa selama tindakan menggunakan model Discovery Learning, kemudian dihitung jumlah dan rata-rata, serta untuk hasil belajar dihitung jumlah siswa tuntas dan tidak tuntas berikut persentasenya. Dari hasil diperoleh bahwa penggunaan model pembelajaran discovery learning dapat meningkatkan hasil belajar siswa kelas XMIA 5 pada pelajaran Biologi kompetensi dasar Plantae di MAN 2 Kota Bandung. Dibuktikan dengan meningkatnya hasil belajar siswa setelah tindakan (siklus I dan siklus II). Tingginya hasil belajar tersebut disertai dengan meningkatnya hasil belajar siswa setelah tindakan dimana diperoleh Dilihat dari rata-rata nilai, pada pra siklus diperoleh 56,94, meningkat pada siklus I menjadi 75,44, serta meningkat lagi pada siklus II menjadi 83,82. Dilihat dari rasio peningkatan dari pra siklus ke setelah tindakan siklus I diperoleh peningkatan 18,5 angka dan setelah tindakan siklus II sebesar 8,35 angka. Adapun dari tindakan prasiklus ke I ke tindakan siklus II diperoleh peningkatan sebesar 26.88 angka.
\end{abstract}

Kata Kunci: Hasil Belajar., Biologi-Plantae, Model Disvovery Learning.

The purpose of this study is to know the improvement of learning outcomes X grade MIA 5 student on basic biology in Plantae basic competence using Discovery Learning model in MAN 2 Bandung. The method used in this research was classroom action research (PTK). Conducted for 2 cycles. Each cycle was done in 2 times meeting. Data collection techniques used was observation and tests. The data analysis technique takes the description of teacher and student learning activities during the action using the Discovery Learning model, then calculated the number and average, as well as for the learning outcomes calculated the number of complete and unfinished students following percentage. From the results obtained that the use of discovery learning model can improve student learning outcomes in XMIA class 5 on Biology lessons of basic competence Plantae in MAN 2 Bandung. Evidenced by increasing student learning outcomes after action (cycle I and cycle II). The high learning outcomes were accompanied by increased student learning outcomes after the action obtained from the 
average value, in the pre cycle obtained 56.94, increased in the first cycle to 75.44 , and increased again in cycle II to 83.82. Judging from the increase ratio from the pre cycle to after the cycle I action obtained an increase of 18.5 points and after the action cycle II 8.35 points. As for the action before the cycle the action cycle II obtained an increase of 26.88 points.

\section{Keywords: Learning Outcomes, Biology-Plantae, Discovery Learning Mode}

\section{PENDAHULUAN}

Tujuan pendidikan yang telah ditetapkan sebagaimana termaktub dalam Undang-undang Nomor 14 Tahun 2005 tentang Guru dan Dosen bahwa: Guru adalah pendidik profesional dengan tugas utama mendidik, mengajar, membimbing, mengarahkan, melatih, menilai, dan mengevaluasi peserta didik pada pendidikan anak usia dini jalur pendidikan formal, pendidikan dasar, dan pendidikan menengah.

Dalam proses pembelajaran, sebagaimana termaktub dalam Undangundang Nomor 14 Tahun 2005 tentang Guru dan Dosen Pasal 20 Poin a, disebutkan bahwa: Tugas keprofesionalan guru adalah: (1) merencanakan pembelajaran, (2) melaksanakan proses pembelajaran yang bermutu, dan (3) melaksanakan evaluasi pembelajaran. Ketiga indikator pembelajaran itu harus dilaksanakan secara optimal oleh guru guna mencapai tujuan pembelajaran yang telah ditetapkan. Oleh karena itu, sebagaimana diamanatkan Undang-undang tersebut, pada poin b ditegaskan bahwa guru harus meningkatkan dan mengembangkan kualifikasi akademik dan kompetensi secara berkelanjutan sejalan dengan perkembangan ilmu pengetahuan, teknologi, dan seni.

$\begin{array}{llr}\text { Dalam } & \text { standar } & \text { kompetensi } \\ \text { kurikulum } & \text { yang } & \text { diterbitkan }\end{array}$
KEMENDIKUBUD, disampaikan bahwa fungsi dan tujuan mata pelajaran biologi. Mata Pelajaran Biologi berfungsi untuk menanamkan kesadaran terhadap keindahan dan keteraturan alam sehingga siswa dapat meningkatkan keyakinan terhadap Tuhan Yang Maha Esa sebagai warga negara yang menguasai sains dan teknologi untuk meningkatkan mutu kehidupan dan melanjutkan pendidikan. Mata Pelajaran Biologi bertujuan untuk:

1. Memahami konsep-konsep biologi dan saling keterkaitannya.

2. Mengembangkan keterampilan dasar Biologi untuk menumbuhkan nilai serta sikap ilmiah.

3. Menerapkan konsep dan prinsip Biologi untuk menghasilkan karya teknologi sederhana ang berkaitan dengan kebutuhan manusia.

4. Mengembangkan kepekaan nalar untuk memecahkan masalah yang berkaitan dengan proses kehidupan dalam kejadian sehari-hari.

5. Meningkatkan kesadaran akan kelestarian lingkungan.

6. Memberikan bekal pengetahuan dasar untuk melanjutkan pendidikan.

Tuntutan profesionalisme guru dalam pembelajaran harus lebih optimal, manakala diperoleh prestasi belajar siswa dalam mata pelajaran yang diampunya rendah. Salah satunya dialami oleh penulis, dimana prestasi belajar pada mata pelajaran Biologi materi Plantae masih rendah, padahal tumbuhan merupakan objek yang tidak asing bagi siswa, namun ketika dihadapkan pada konsep-knsep yang berbasis nama ilmiah, tata nama, klasifikasi, dan berbagai manfaat bahkan yang sederhada tidak jarang siswa mengalami kesulitan. Berdasarkan hasil pendahuluan siswa hanya 10 siswa atau $29,41 \%$ yang sudah tuntas, dan sebanyak 24 siswa atau $70,59 \%$ belum tuntas dengan rata-rata nilai 29,41 . KKM yang ditentukan sebesar 75 . 
Data rendahnya prestasi belajar siswa tersebut merupakan masalah bagi penulis yang harus diselesaikan. Salah satu yang penulis lakukan adalah dengan memperbaiki kualitas pembelajaran melalui penerapan suatu model pembelajaran. Perbaikannya penulis tempuh melalui penelitian tindakan kelas (PTK).

Untuk mengantisipasi permasalahan tersebut, penulis mengidentifikasi pokok permasalahan yang terjadi. Salah satu identifikasinya yakni belum tepatnya model pembelajaran yang diterapkan. Oleh karena faktor model, maka alternatif untuk memecahkannya adalah melakukan uji coba model pembelajaran. Model pembelajaran yang diterapkan dalam penelitian ini adalah model pembelajaran Bruner memakai model yang disebutnya Discovery Learning, di mana murid mengorganisasi bahan yang dipelajari dengan suatu bentuk akhir (Dalyono, 1996:41). Model Discovery Learning adalah memahami konsep, arti, dan hubungan, melalui proses intuitif untuk akhirnya sampai kepada suatu kesimpulan (Budiningsih, 2005:43). Discovery terjadi bila individu terlibat, terutama dalam penggunaan proses mentalnya untuk menemukan beberapa konsep dan prinsip. Discovery dilakukan melalui observasi, klasifikasi, pengukuran, prediksi, penentuan dan inferi. Proses tersebut disebut cognitive process sedangkan discovery itu sendiri adalah the mental process of assimilatig conceps and principles in the mind (Robert $\mathrm{B}$. Sund dalam Malik, 2001:219).

\section{METODE PENELITIAN}

Metode penelitian ini adalah penelitian tindakan kelas (PTK). Dalam penelitian ini penulis memilih metode Penelitian Tindakan Kelas (PTK) karena diharapkan dapat dimanfaatkan untuk memperbaiki pembelajaran dikelola di kelas, serta mendapat kesempatan untuk berperan aktif dalam mengembangkan pengetahuan dan keterampilan sendiri.

Arikunto (2006), berpendapat bahwa penelitian tindakan kelas (PTK) adalah penelitian yang dilakukan oleh guru di dalam kelasnya sendiri melalui refleksi diri, dengan tujuan untuk memperbaiki kinerjanya sebagai guru sehingga hasil belajar siswa menjadi meningkat. PTK adalah bentuk proses pengkajian berdaur (siklus) yang terdiri dari empat tahap yaitu: (1) perencanaan (planning), (2) tindakan (action), (3) pengamatan (Observation), (4) refleksi (reflection).

Tahap perencanaan (planning) dalam PTK merupakan suatu langkah untuk menyusun rencana pelakksanaan pembelajaran, instrumen-instrumen, alat dan media, serta lainnya yang berhubungan dengan pelaksanaan siklus I maupun siklus II. Dengan demikian, pada perencanaan ini dibuat terencana dan matang.

Tahap pelaksanaan tindakan (action) dalam PTK merupakan kegiatan tindakan pembelajaran setiap siklusnya. Tahap tindakan ini memrupakan tahap penerapan metode yang digunakan untuk alternatif pemecahan permasalahan kelas.

Tahap pengamatan (observation) dalam PTK merupakan tahap mengamati jalannya proses pembelajaran. Proses pembelajaran yang diamati meliputi kegiatan pembelajaran yang dilakukan guru dan aktivitas belajar siswa.

Tahap refleksi (reflection) dalam PTK merupakan suatu tahap analisis terhadap hasil observasi dan tes hasil belajar. Apa yang sudah dilakukan dan apa yang belum dilakukan peneliti. Juga selain itu, mana yang sudah baik dan masih kurang dilakukan oleh guru maupun siswa. Refleksi ini sangat penting bagi perbaikanperbaikan tindakan siklus berikutnya.

\section{HASIL DAN PEMBAHASAN}

\section{A. Hasil}

Setelah melakukan tindakan Siklus I dan Siklus II, diperoleh deskripsi hasil sebagai berikut: 
Tabel 1. hasil evaluasi siklus

\begin{tabular}{|r|l|r|r|r|}
\hline No & Deskripsi & Pra siklus & Siklus I & Siklus II \\
\hline 1 & Tuntas & $10(29,41 \%)$ & $25(73,53 \%)$ & $32(94,12 \%)$ \\
\hline 2 & Tidak Tuntas & $24(70,59 \%)$ & $9(26,47 \%)$ & $2(5,88 \%)$ \\
\hline
\end{tabular}

\section{1) Prestasi Belajar Siklus I}

Setelah melakukan tes diperoleh hasil sebagai berikut:

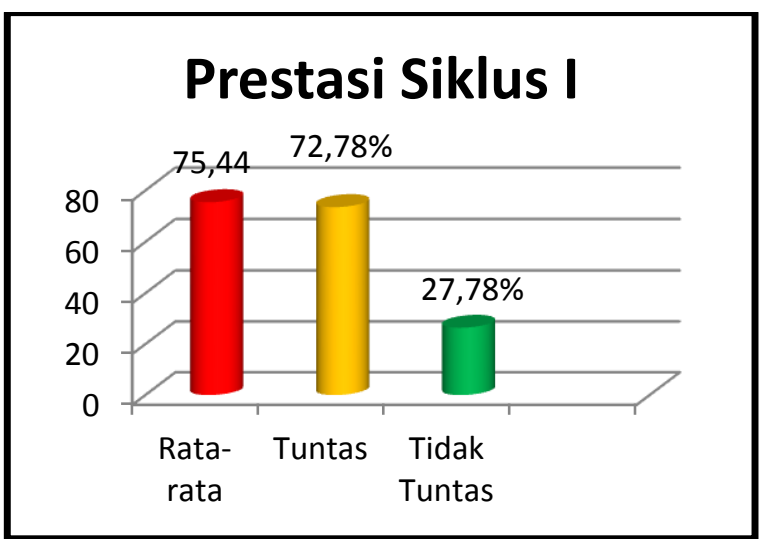

Gambar 1. Grafik prestasi siklus I

Dari tabel dan grafik di atas, dapat ditafsirkan diperoleh prestasi belajar pada tindakan siklus I yakni: rata-rata nilai 75,44 , jumlah siswa tuntas sebanyak 25 $(73,53 \%)$, dan jumlah siswa tidak tuntas sebanyak 9 siswa $(26,47 \%)$.

\section{d. Refleksi Tindakan Siklus I}

Setelah tindakan siklus I, kemudian dilakukan diskusi dengan observer atas hasilnya, maka diperoleh refleksi sebagai berikut:

1) Pada kegiatan guru, masih terdapat beberapa indikaktor yang harus diperbaiki pada tindakan siklus II, yakni:

(1) Pada indikkator melakukan apersepsi, dikategorikan cukup baik. Sehingga memerlukan perluasan eksplorasi pada siklus II dengan memperbanyak pertanyaan.

(2) Pada indikkator mengelompokkan siswa, dikategorikan cukup baik.
Pengelompokkan cukup baik namun memakan waktu lama, sehingga pada siklus II perlu dipersiapkan pada awal pembelajaran.

(3) Pada indikkator membimbing kelompok pada saat bekerja, dikategorikan cukup baik, dan terlihat belum optimal. Sehingga perlu dipersiapkan intruksi secara tertulis atau tampilan poin-poin intruksi serta pembimbingan harus lebih intensif agar kelompok mampu menyusun laporan dengan baik.

(4) Pada indikkator melakukan post tes, dikategorikan cukup baik, dan belum menggambarkan tingkat penguasaan siswa terhadap materi secara acak agar diperoleh hasil secara merata.

2) Pada aktivitas belajar siswa, masih terdapat beberapa indikaktor yang harus diperbaiki pada tindakan siklus II, yakni:

(1) Menyimak penjelasan guru tentang tujuan dan ruang lingkup materi pembelajaran, dikategorikan cukup aktif kkarena masih ada beberapa siswa yang masih gaduh. Sehingga diperlukan penekanan intruksi dari guru agar siswa lebih menyimak.

(2) Terlibat dalam apersepsi, dikategorikan cukup aktif, sehingga guru harus lebih menggali lebih dengan memperbanyak pertanyaan.

(3) Aktivitas menyimak cara kerja metode yang digunakan, dikategorikan cukup aktif karena masih ada beberapa siswa yang gaduh oleh karena itu, guru harus 
menjelaskan tata kerja model ini sejak awal, sehingga siswa lebih siap.

(4) Aktivitas menyimak kelompok yang melakukan presentasi di depan, dikategorikan cukup aktif. Oleh karena itu, harus mendapat penegasan lagi dari guru agar semuanya menyimak.

(5) Aktivitas berdiskusi dengan kelompok lain dan Aktivitas bertanya atau berpendapat ketika diskusi, dikategorikan cukup aktif. Oleh karena itu perlu diberi reward dari guru.

(6) Aktivitas dalam bertanya dan berpendapat ketika berdiskusi dikategorikan cukup aktif, sehingga perlu diberi motivasi agar lebih aktif bertanya dan berpendapat.

3) Prestasi belajar siswa kelas X MIA 5 pada materi Plantaecukup memuaskan, oleh karena ingin ditingkatkan pada tindakan siklus II.

\section{Deskripsi Hasil Tindakan Siklus II \\ a. Perencanaan Siklus II}

Sebelum melaksanakan tindakan siklus II, terlebih dahulu direncanakan halhal berikut:

1) Menyusun rencana pembelajaran siklus II.

2) Menyiapkan alat dan media pembelajaran siklus II: ATK, kartn ertas warna, spidol, pensil, dan mistar.

3) Menyusun instrumen siklus II: (1) Lembar observasi kegiatan guru siklus II, (2) Lembar observasi belajar siswa siklus II, dan (3) Soal tes siklus II.

\section{b. Pelaksanaan Tindakan Siklus II \\ 1) Prestasi Belajar Siklus II}

Setelah melakukan tes diperoleh hasil sebagai berikut:

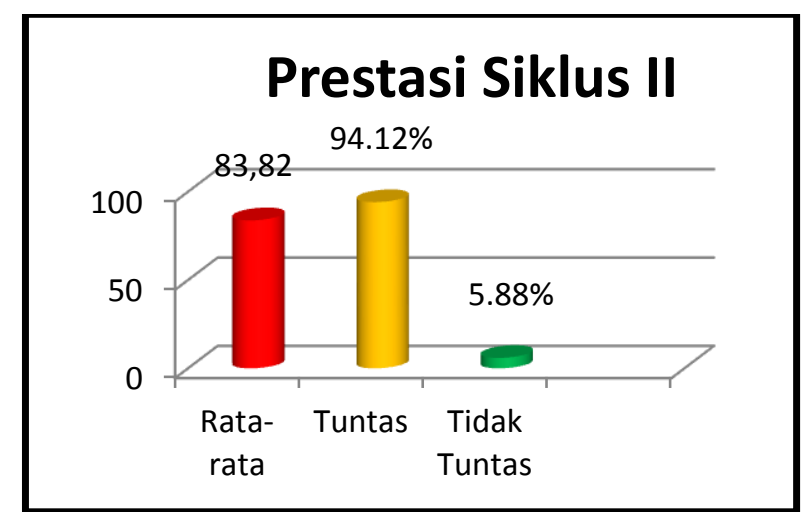

Gambar 2. Grafik prestasi belajar siklus II

Dari tabel dan grafik di atas, dapat ditafsirkan diperoleh prestasi belajar pada tindakan siklus II yakni: rata-rata nilai 83.82, jumlah siswa tuntas sebanyak 25 (94,12\%), dan jumlah siswa tidak tuntas sebanyak 2 siswa $(5,88 \%)$.

\section{B. Pembahasan}

Dari hasil penelitian sebanyak dua siklus dapat dapat dibahas sebagai berikut:

\section{Pembahasan Kegiatan Guru dalam Proses Pembelajaran}

Dari hasil penelitian siklus I dan siklus II diperoleh bahwa pada tindakan siklus I terdapat beberapa indikator yang berkategori baik. Namun demikian, masih terdapat pula beberapa indikator yang berkategori cukup baik dan harus diperbaiki pada tindakan siklus II. Indikator-indikator yang harus diperbaiki itu, merupakan tahapan-tahapan inti dari penerapan model discovery learning.

Atas hasil refleksi dari siklus I, pada tindakan siklus II, indikator yang berkategori baik, berdasarkan penilaian observer meningkat menjadi berkategori sangat baik. Sedangkan indikator-indikator yang berkategori cukup baik meningkat menjadi sangat baik.

Peningkatan perbaikan pembelajjaran yang dilakukan guru, tidak terlepas dari hasil refleksi siklus I. Refleksi siklus I, dihasilkan setelah berdiskusi dengan observer. 


\section{Pembahasan Aktivitas Belajar Siswa}

Dari hasil penelitian siklus I dan siklus II diperoleh bahwa pada tindakan siklus I terdapat beberapa indikator yang berkategori aktif Namun demikian, masih terdapat pula beberapa indikator yang berkategori cukup aktif dan harus diperbaiki pada tindakan siklus II. Indikator-indikator yang harus diperbaiki itu, merupakan keharusan keterlibatan siswa dalam proses discovery dan dalam kelompoknya masing-masing.
Berdasarkan hasil refleksi dari siklus I, pada tindakan siklus II, indikator yang berkategori cukup aktif, berdasarkan penilaian observer meningkat menjadi berkategori aktif. Hal ini berarti ada peningkatan perbaikan belajar siswa yang tentunya merupakan dampak perbaikan mengajar guru.

\section{Pembahasan Prestasi Belajar}

Berikut penulis sajikan tabel dan gambarnya:

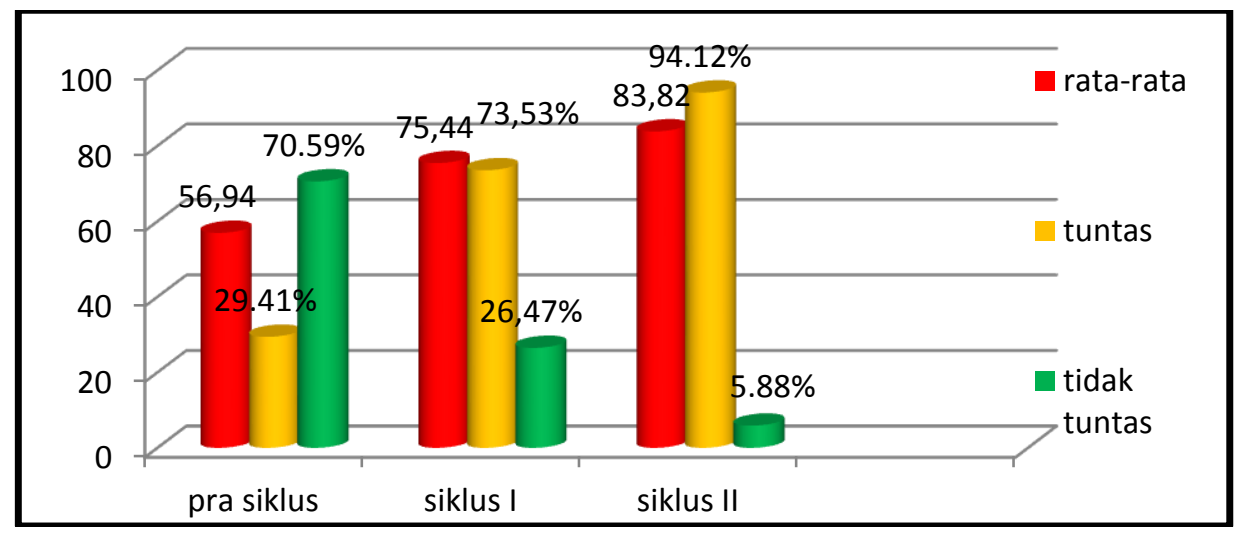

Gambar 3 Prestasi Belajar Siswa Pra-Siklus, Siklus I, dan Siklus II

Dari tabel dan grafik di atas, dapat penulis bahas terjadi peningkatan prestasi belajar siswa dari prasiklus dan setelah siklus. Dilihat dari rata-rata nilai, pada pra siklus diperoleh 56,94, meningkat pada siklus I menjadi 75,44 , serta meningkat lagi pada siklus II menjadi 83,82. Dilihat dari rasio peningkatan dari pra siklus ke setelah tindakan siklus I diperoleh peningkatan 18,5 angka dan setelah tindakan siklus II sebesar 8,35 angka. Adapun dari tindakan prasiklus ke I ke tindakan siklus II diperoleh peningkatan sebesar 26.88 angka.

Dilihat dari ketuntasan belajar, pada prasiklus diperoleh sebanyak 10 siswa $(29,41 \%)$ yang tuntas, meningkat pada siklus I menjadi 25 siswa $(73,53 \%)$, serta meningkat lagi pada siklus II menjadi 32 siswa $(94,12 \%)$.

Dilihat dari ketidaktuntasan belajar, pada prasiklus diperoleh sebanyak 24 siswa $(70,59 \%)$ yang tidak tuntas, menurun pada siklus I menjadi 9 siswa $(26.47 \%)$, serta menurun lagi pada siklus II menjadi 2 siswa $(5.88 \%)$.

Berdasarkan hasil di atas, terlihat bahwa tujuan PTK yang memiliki sifat pe,belajaran berbais reflektif. telah ter capai dalam menigkatkan hasil belajar siswa. Demikin pula dengan model pembeajaran discover learning Membantu siswa untuk memperbaiki dan meningkatkan keterampilan-keterampilan dan proses-proses kognitif. Usaha penemuan merupakan kunci dalam proses ini, seseorang tergantung bagaimana cara belajarnya. Pengetahuan yang diperoleh melalui model ini sangat pribadi dan ampuh karena menguatkan pengertian, ingatan dan transfer. Menimbulkan rasa senang pada siswa, karena tumbuhnya rasa 


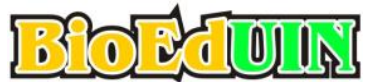

Jurnal Program Studi Pendidikan Biologi

menyelidiki dan berhasil. Model ini memungkinkan siswa berkembang dengan cepat dan sesuai dengan kecepatannya sendiri. Menyebabkan siswa mengarahkan kegiatan belajarnya sendiri dengan melibatkan akalnya dan motivasi sendiri.

Atas dasar pembahasan hasil kegiatan guru, belajar siswa, serta prestasi belajar yang diperoleh, dapat penulis jawab hipotesis tindakan penelitian ini bahwa ternyata: penggunaan model pembelajaran discovery learning dapat meningkatkan prestasi belajar siswa Kelas X MIA 5 pada pelajaran biologi materi Plantae di MAN 2 Kota Bandung.

\section{DAFTAR PUSTAKA}

Arifin,1991, Pengantar Ilmu Pendidikan, Bandung: Pustaka Setia.

Arikunto, Suharsimi, 2006, Penelitian Tindakan Kelas. Jakarta: Bumi Aksara.

Djamarah, Syaiful Bahri, 1994, Strategi Belajar mengajar. Jakarta: PT Rineka Cipta.

D.A Pratiwi Dkk Biologi 1 SMA, Erlangga Istamar Syamsuri Dkk Biologi jilid 1 SMA
p-ISSN : 2338-7173

e-ISSN : 2615-0417

(Februari), Vol. (8), No.(1)

Faturrohaman, Pupuh, 2007, Strategi Pembelajaran. Bandung: Insan Media

Moleong, Lexy, 2004, Metode Penelitian Kualitatif. Bandung: Remaja Rosdakarya.

Roestiyah, 1989, Strategi Belajar Mengajar. Jakarta : Rineka Cipta.

Sanjaya, Wina, 2008, Strategi Pembelajaran Beorientasi Standar Proses Pendidikan. Jakarta: Kencana.

Sardiman, 1999, Interaksi dan motivasi Belajar Mengajar. Jakarta: PT. Raja Grafindo Persada

Sudjana,1998, Dasar-dasar Belajar Mengajar. Bandung: Tarsito

Suprijono, Agus, 2009. Cooperative Learning Teori dan Aplikasi Paikem. Yogyakarta :Pustaka Pelajar

Suryabrata, Sumadi, 1998, Psikologi Pendidikan. Jakarta : Rajawali

Syah, Muhibbin, 2008, Psikologi Belajar, Jakarta: Logos.

Tim KBBI, 1993, Kamus Besar Bahasa Indonesia. Jakarta.

Undang-undang Nomor 14 Tahun 2005, Guru dan Dosen. Diknas: Jakarta. 